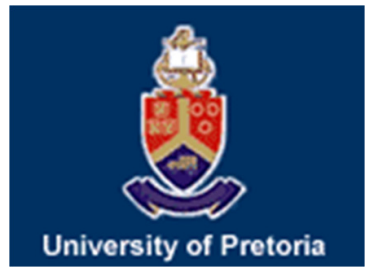

University of Pretoria

Department of Economics Working Paper Series

Water Taxation and the Double Dividend Hypothesis

Nicholas Kilimani

University of Pretoria

Working Paper: 2014-51

October 2014

Department of Economics

University of Pretoria

0002, Pretoria

South Africa

Tel: +27 124202413 


\title{
Water Taxation and the Double Dividend Hypothesis
}

\author{
Nicholas Kilimani ${ }^{1}$
}

September 2014

\begin{abstract}
The double dividend hypothesis contends that environmental taxes have the potential to yield multiple benefits for the economy. However, empirical evidence of the potential impacts of environmental taxation in developing countries is still limited. This paper seeks to contribute to the literature by exploring the impact of a water tax in a developing country context, with Uganda as a case study. Policy makers in Uganda are exploring ways of raising revenue by taxing environmental goods such as water. Whereas their primary focus is to raise revenue, we demonstrate how taxes on environmental goods can yield other benefits beyond addressing a country's fiscal needs.

This study employs a computable general equilibrium model to shed light on the impact of a water tax policy when a tax is accompanied by a recycling scheme of the same magnitude. We seek to establish whether taxation and recycling can induce more growth, employment and industry output. The results show that a mechanism which leaves a neutral fiscal balance yields dividends for the economy. In other words, whatever the degree of regressivity resulting from the environmental tax, it is possible to design a recycling scheme that renders the tax policy to be beneficial to the economy.
\end{abstract}

JEL Classification code: $\mathrm{C} 68 ; \mathrm{H} 23 ; \mathrm{E} 62 ; \mathrm{Q} 52$

Key words: Environmental Taxation; Revenue recycling; Double dividend; Economic growth

\section{Adknowledgments}

This paper is part of a wider thesis research programme which will lead to the award of a Doctor of Philosophy Degree of the University of Pretoria. In this regard, the Author would like to thank his thesis Advisors: Prof. Jan van Heerden and Dr. Heinrich Bohlmann for making this study possible. This is in addition to the very useful comments from ERSA's anonymous reviewers. All errors and omissions remain mine.

\footnotetext{
${ }^{1}$ Corresponding author email: $\underline{n}$ kilimani@yahoo.com; nick.kilimani@up.ac.za Tel: +27718334525; +256772440724

Department of Economics

University of Pretoria

Private bag X20

Hatfield 0028

South Africa
} 


\section{Introduction}

A number of developing countries are experiencing both economic and environmental challenges. Similarly, the ability for these countries to pursue their development goals is often inhibited by a lack of resources. In order to realize their goals, several countries have employed a combination of measures which have instead altered their pattems of production and consumption, leading to substantial economic costs. This has necessitated the need to put into place measures that are capable of minimizing the costs of environmental regulation while achieving the desired economy-wide behavioral changes [Yusuf et al. (2007)]. As a result, policy-makers are increasingly paying attention to the potential for incentive-based environmental regulation, i.e., through economic instruments. This is because this approach has the potential to generate additional govemment revenues -in the form of environmental tax receipts or the proceeds of auctioned emissions trading allowances, depending on the setting. This has led to the need to develop a closer link between environmental policy and tax policy [Fullerton (2008)]. This need is borne out of the recognition that on the one hand, the new government revenues may provide an opportunity for tax reform. On another hand, the availability of environmental taxes alters the constraints and costs of a prevailing tax policy. Specifically, the new taxes in addition to the existing ones may have a distortionary impact on the labour and capital markets.

\subsection{Problem statement}

There is evidence in the literature which suggests that an environmental tax policy generates revenues which can be used to reduce other distortionary taxes and thus produce benefits in addition to those that result from the reduced water use or emissions. Several arguments have been put forward in relation to the use as well as benefits and costs of environmental policy in several countries [see Goulder (1995); Brouwer et al. (2008); Tol et al. (2008); Zhou and Segerson (2012) and Katri (2012)]. However, the potential for the existence of dividends cannot be taken for granted. For instance, the replacement of part of the politically sensitive taxes like labor income tax with environmental taxes may be seen as an environmentally attractive way of increasing the potential for labor demand thereby by creating employment. In fact, such tax reforms have been proposed and implemented in several countries [Letsoalo et al. (2007); Patuelli et al. (2005)]. However, some economists have been more skeptical about the potential gains from such interventions and as a consequence, the issue has become a subject of extensive research [see Schöb (2009); Zhou and Segerson(2012)].

Given the lack of consensus regarding the impacts of environmental taxation, this study is worth undertaking. In addition, there is limited empirical evidence about the effects of imposing such taxes in developing economies. There is therefore the need to contribute to this limited evidence for the case of developing countries. This is critical since it is these developing countries that are faced with the challenges of managing environmental resources as well as constraints to sources of revenue mobilization. Furthermore, there is limited use of environmental taxes both revenue generation as well as environmental management. In fact, the quest for revenue generation has instead led to the imposition of a number of taxes some of which may be distortionary to the economy. It is for this reason that a developing economy like Uganda provides an interesting case study since most of the existing studies are based on developed and middle income economies [see e.g., Van Heerden et al. (2006); Letsoalo et al. (2007); 
Blignaut et al. (2008) for South Africa; Diao and Roe (2003) for Morocco; Brouwer et al.(2008) and Pulido-Velázquez et al. (2008) for Europe]. In line with the developments in the economic and environmental policy arena, this paper seeks to analyze the impact of a tax on water in a developing country context with Uganda as a case study. This study is timely given the fact that during the 2013/14 fiscal year, the Ministry of Finance Planning and Economic Development (MFPED) proposed to apply a Value Added Tax on water. This tax measure was aimed at improving tax administration and generating revenue [See MFPED, Budget Speech (2013), page 44]. Since the use of environmental tax instruments has not been a common policy measure in Uganda, the proposed intervention constitutes an interesting policy research issue that is worth investigating. The study is aimed at investigating the benefits of environmental taxation beyond revenue generation. It is critical to undertake a study that assesses the impact of such an intervention from an economy-wide perspective.

\subsection{Contribution}

The study seeks to make a number of contributions to both literature and policy with regard to the issue under investigation. First, there is empirical evidence to suggest that taxes on water resources can yield multiple benefits for the economy if implemented on the basis of equity [See e.g., Rosegrant et al. (2002); Van Heerden et al. (2006); Letsoalo et al. (2007) and Blignaut et al. (2008)]. However, the economy-wide impacts are most likely to vary depending on the context and cannot therefore be known apriori [EEA (2011)]. In this regard, policymakers need to understand these impacts in order to balance between the need to maximize the aggregate gains from these tax reforms and the rights to equitable sharing of the associated costs and benefits.

Second, water resources are increasingly becoming stressed in terms of quantity and quality across the globe. These strains are emanating from economic activity, demographic trends as well as severe changes in climate [Bates et al. (2008); Tol et al. (2008)]. Projections indicate increased rainfall in high altitudes, and decreased rainfall in the low lying areas [IPCC (2001)]. In addition, the increase in temperatures implies larger water demand and higher rates of evaporation, all of which combine to aggravate the problem. In Uganda, changes in climatic conditions are being experienced through increased rainfall volatility across seasons and rising temperatures [FEWSNET (2012)]. These changes in climate have implications for future water resources availability with ramifications for poverty reduction, employment and food security [Rosegrant et al. (2007)].

Whereas the adverse effects of these climatic changes have become central to the debate on issues of long-term global, social and economic stability, the policy interventions in Uganda do not seem to be paying adequate attention to the long term impact of water resource availability from an economic point view. In fact, most of the existing studies on water resources in Uganda have focused mostly on hydrological aspects. This is despite the fact some of the country's economic challenges seem to be emanating from developments in the water sector [See MFPED (2011),p.80]. Amidst these challenges, Uganda has a substantial volume of water resources that could be utilized to mitigate the water related challenges in the economy. For instance, approximately 25 percent of country's surface area is covered by fresh water sources [DWRM(2011)]. However, critical sectors such as agriculture are still rainfall dependent. This is largely because the existing infrastructure to ensure optimal water use is limited. It is therefore critical that measures are put into place to hamess resources that can be used to finance the development and expansion of water infrastructure. In this regard, a tax on water may therefore be one of the options. 
The framework for analysing interventions which are aimed at efficient management of water resources through taxation has its foundations in Pigou (1920). Proponents of the use of environmental taxes argue that they are efficient instruments not only for protecting the environment but for generating other benefits for the economy. This is referred to as "double dividends" in the literature. This study therefore seeks to add to the existing empirical evidence by assessing the possibility of the existence of "double dividends" in the case of Uganda. The hypothesis asserts that economies stand to gain from the imposition of environmental taxes through environmental conservation, revenue generation, employment, poverty reduction, and overall economic growth via the "revenue recycling" effects. Pearce (1991) and Oates (1995) argue that an environmental tax has the likelihood of conserving the environment as well as generate revenue that can be used to reduce other distortionary taxes on employment, investment and consumption. In fact Schöb (2009) argues that tax related policy interventions are superior to other environmental policy instruments, such as command and control. In addition, there are other benefits that accrue if some of the realised tax revenue is invested in the provision of safe water. For example, the expansion of piped water infrastructure in Argentina during the 1990s reduced child mortality by 8 percent [Galiani et al. (2005)]. Other studies find that access to safe water reduces childhood exposure to pathogens in drinking water which may improve long-run health and educational outcomes [Venkataramani (2009)].

This paper therefore seeks to investigate the impact of a tax on water on the Ugandan economy because there is the need to investigate whether environmental taxes can generate positive impacts in a developing country. Whereas related studies exist, these are limited and have been undertaken in different contexts and motivations. Some studies have been undertaken for developed or upper-middle income countries [see e.g., Van Heerden et al. (2006); Letsoalo et al. (2007); Blignaut et al. (2008) for South Africa; Diao and Roe (2003) for Morocco; Brouwer et al.(2008) and Pulido-Velázquez et al. (2008) for Europe]. Other studies have focused their investigation on a global scale [See Berrittella et al. (2007) and Tol et al. (2008) in their analysis of the impact of tax on water on production, consumption, and international trade pattems]. Others focus on optimal water use in specific sectors [ see Berrittella et al. (2007); Blignaut et al. (2008); and Wittwer (2011)] while others have been carried out under situations of water scarcity [See Letsoalo et al. (2007); Calzadilla et al. (2008); Calzadilla et al. (2010) and Qin et al. (2012)].

This study seeks to analyse the impact of an environmental tax first, with the view to assess its feasibility as a revenue mobilization tool. This is aimed at forming a basis for the future use of related policy instruments to generate revenue for the economy. Second, the study is aimed at investigating whether a tax is an effective instrument for environmental regulation to the extent that it can induce efficient water use. This is borne from the fact that whereas the country has sufficient water in the immediate term, projections show that it might not be the case in the long term [See MWE (2009)]. As water becomes scarce, interventions are needed to economize on its use. In most developing countries, the mechanisms for efficient utilization of water are largely absent. These range from small scale and obsolete irrigation infrastructure to the low levels of water charges. These do not encourage efficient use [Seckler et al. (1998) and Tol et al. (2008)]. It is therefore argued that a tax would increase the price of water which in turn, would lead to the adoption of efficient ways of utilizing it [See e.g., Dinar and Yaron (1992)]. 
Third, some studies use partial equilibrium models in order to assess the impact of water resource policies on the economy [See Rosegrant et al. (2002); Sahibzada (2002); Gopalakrishnan and Cox (2003) and De Fraiture et al. (2004)]. These do not provide adequate analysis of issues whose impacts are bound to be economy-wide [Faust et al. (2012)]. Some studies use Input-Output models to analyze the impact of water resource policies on the economy [Delgado, et al. (1998); Hassan and Olbrich (1999); Rose et al. (2000); Bautista et al. (2002) and Juana and Mabugu (2005)]. Whereas I-O models provide for a general equilibrium environment in which one can trace the multiplier or feedback effects in order to perform distributional impact analysis, these models lack the standard statistical properties [See Leontaritis and Billings (1985); Duchin (1992) and Miller and Blair (2009)]. In addition, the linearity assumption of basic input-output models and the absence of market and price considerations make them to be less favorable. Some studies assess the impact of policies using virtual water [Allan and Olmstead (2003)]. Others use global models to assess the impact water resource policies on the economy [See Seckler et al. (1998); Alcamo et al. (2000); Yang et al. (2003) and Berittella et al. (2007)]. Given the aggregation and assumptions which are made when developing such models, their accuracy may be questionable. Those that use CGE models mostly focus on the impact of water resource policies on specific sectors of the economy [Decaluwé et al. (1999); Diao and Roe (2003); Van Heerden et al. (2006)] or regions of the economy in some cases [see e.g., Goodman (2000); Gómez etal. (2004)].

In this paper, we use a CGE model that has been specially developed using Ugandan data to analyze the impact of a tax on water on the Ugandan economy. A specially developed computable general equilibrium model is used to investigate the economywide feedbacks and the welfare implications of the proposed tax intervention. The rest of the paper is organized as follows: Section 2 provides an over view of the developments in water sector in Uganda and the associated social-economic trends, section 3 highlights the key issues in the literature with respect to the double dividend hypothesis, while the analytical framework and data issues are discussed in section 4. Simulation results are presented in section 5, followed by the discussion in section 6 . Section 7 presents the emerging issues arising from the study.

\section{The Water sector and Uganda's economy}

Discussions of water issues regularly highlight the importance of water for food security and public health as well as its contribution to the transformation of agro-based developing economies. Water related policies have therefore become central on the agenda of the international community [Chumi and Dudu (2008)]. For instance, among the targets for the Millennium Development Goals is MDG 7 which seeks to ensure environmental sustainability [United Nations (2007)]. The target is to ensure "reduction by half, the proportion of people without sustainable access to safe drinking water and basic sanitation by 2015". Haller et al. (2007) in their study of the economic retums on investments in water supply and sanitation indicate that every US\$1 spent on water supply and sanitation services yields an economic return of approximately 5-46US\$, with the highest returns going to the least-developed areas. Much of this additional income accrues from the time saved by having reliable water supply close to the household [Hunter et al. (2010)]. Studies show that inadequate water supply is a contributor to many deaths in children under 5 years [Prüss and Havelaar (2001); Fewtrell et al. (2005)]. 
Studies also show that investment in water can induce a reduction in poverty [Hanjra and Gichuki (2008)]. It can therefore be argued that adequate water and sanitation is an essential prerequisite for economic development. Poor countries with access to improved water have been cited to experience an average annual growth of 3.7\%. On the other hand, countries with the same per capita income but without such access have an annual growth rate of only 0.1\% [SIWI (2005)]. In Uganda, water is central to supporting production across different sectors of the economy [MWE (2009)]. In developing countries, constraints to water supply, whether for productive or domestic uses, are shown to have direct and adverse impacts on livelihoods [Grey and Sadoff (2007) and Hunter et al. (2010)]. This relationship between water resources and the economy is demonstrated by the Ministry of Water and Environment in an analysis of the effects of droughts on the agricultural sector [DWRM (2011)]. In periods of drought, all crops in the nine distinct farming systems in the country experience a moisture deficit ranging from $128-251 \mathrm{~m}^{3}$ for perennial crops and $128-242 \mathrm{~m}^{3}$ for non-perennial crops. Hence, any sustained period of drought can have adverse effects on the economy.

Several studies urge the need for investments in low-cost water harvesting techniques, irrigation, and clean water provision as a means of increasing food production and reducing the infectious disease burden [Rosegrant and Miejer (2002b); Sanchez and Swaminathan (2005)]. In Sub-Saharan Africa and south Asia for instance, access to a small amount of irigated land has transformed food security for the highly vulnerable households [Mathew (2005)]. In Uganda, consequences of the absence of low cost water harvesting techniques and imigation are demonstrated by an assessment by OPM (2012) who cite how rainfall deficits severely affect food security in the country. The decline in agricultural output presents a knock-on effect on food prices leading to further macroeconomic instability. The study estimated that the value of damage and losses caused by the rainfall deficit was approximately US\$1.2 billion equivalent to 7.5 percent of GDP in 2010. Figure 1 highlights the losses which accrued from this shock. The adverse effects of the shock were highly felt in the productive sectors of the economy. A breakdown of the sectoral effects shows that the livestock sub-sector lost UGX 1.1 trillion while the production of food and cash crops registered UGX 1.0 trillion in damages and losses. There were losses in agro-industry of UGX 278.0 billion; commerce lost sales of approximately UGX 169.9 billion; while electricity production losses amounted to UGX 106.3 billion. In addition, there were effects on other sectors such as sanitation, health care provision and nutrition assistance, education as well as food aid to the severely affected regions. 


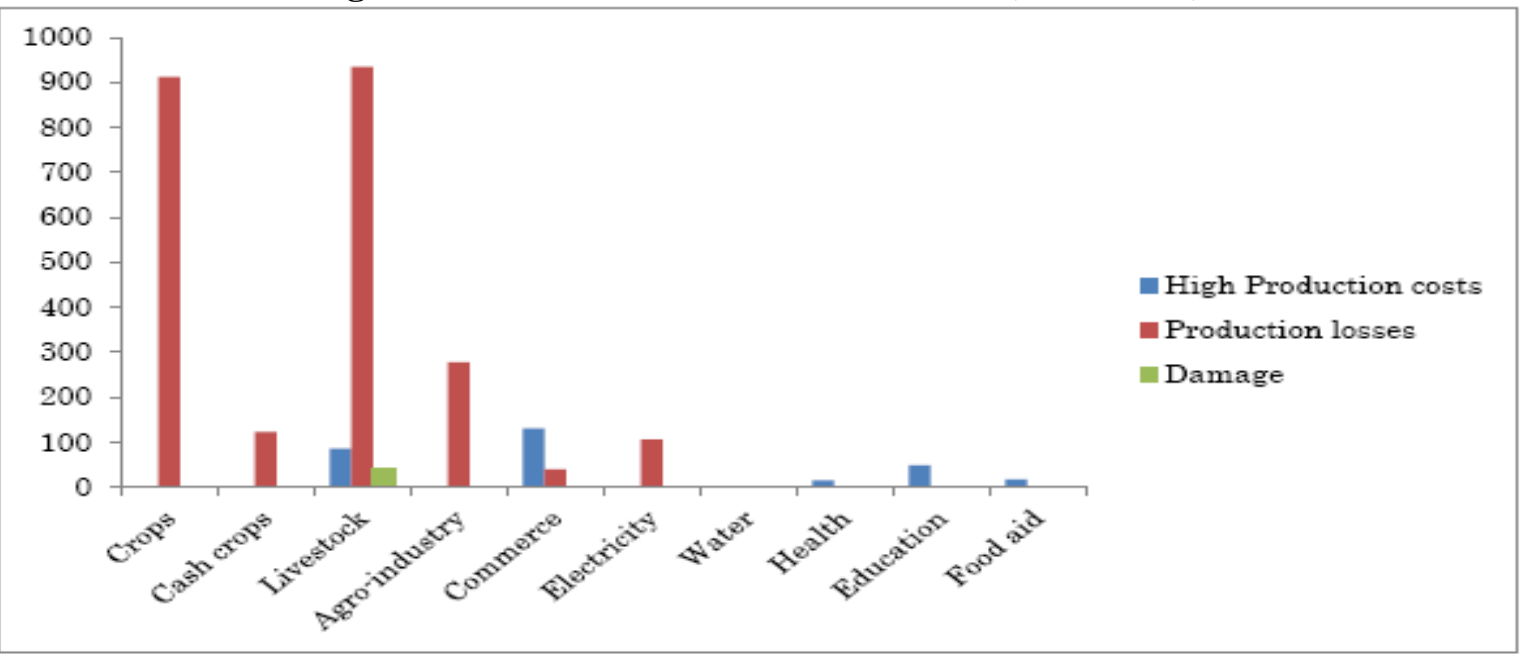

Source: OPM (2012)

Amidst these water related challenges, the country is endowed with a substantial amount of fresh water from the different sources which can be utilised to address some of the challenges which the economy is facing. The total volume of renewable resources is estimated at approximately 43.3 billion $\mathrm{m}^{3}$ [DWRM (2011)]. With regard to surface water, there are eight major catchment areas which drain into other water bodies within and outside the country. According to DWRM (2011), the estimated renewable groundwater resources exceed current projections of demand for domestic water supply by a substantial margin. This is with respect to areas which are not served under the piped water distribution network. Projections indicate that the sustainable utilization rate for the year 2030 is below $15 \%$ for most areas [DWRM (2011)]. However, these water resources experience both seasonal and spatial variability, a situation which is further being exacerbated by the volatile changes in temperature and precipitation. In fact, Carter and Parker (2009) note that groundwater resources are dependent on rainfall for replenishment and this makes them to be susceptible to climatic variability. Hence uncontrolled abstraction of water can present a danger of causing a fall in water levels and exhaustion of resources [Foster and Chilton (2003)].

Whereas Uganda receives a mean annual rainfall of $1200 \mathrm{~m}^{3}$, the positive effects of this rainfall are eroded by the high rates of potential evaporation which is approximately 75 percent within the range of $1350-1750 \mathrm{~m}^{3}$. This implies that in the absence of sustained rainfall, the ground water recharge capacity in most areas of the country is greatly affected. This is exacerbated by increasing temperature which adversely affects regions where rainfall intensity is less than potential evapo-transpiration. Worse still, effective utilization of the existing water resources is curtailed by a mismatch between the location of the water resources and the regions where demand is high, notably the arid and semi-arid areas of the country [MWE (2009)]. MacDonald et al. (2005) suggest that areas which, in addition to prolonged droughts and sparse populations have no reliable water supply, development of groundwater through natural reservoirs is the only realistic option for significantly improving water coverage. Once such instances of lop-sided availability of water resources are put into account, Kemp et al. (2005) argue that statistics on national water resources prove not to be a good indicator of water scarcity. Their view is that it is critical to have water resources (usually groundwater) close to the point of need. This calls for the need to develop the necessary infrastructure. MacDonald and Calow (2009) conclude 
that inadequate attention to the variability in the nature and occurrence of water resources is a key reason for having expensive and unreliable water supply. This implies that in the absence of the necessary infrastructure, such regions continue to suffer.

In Uganda, current per capita water consumption is still low. However, it is projected to rise gradually from the current $21 \mathrm{~m}^{3}$ to approximately $30 \mathrm{~m}^{3}$ per capita per annum by 2035 . This implies that policies and infrastructure have to be put into place to ensure efficient utilization of water resources. This is related to the fact that water sources across the globe are under threat from pollution through intensive agriculture, industry, and poor sanitation. The ramifications for developing economies are that since expensive water treatment is not affordable, the only option is for people to use contaminated water [Hunter et al. (2010)]. Table 1 highlights Uganda's water demand projections by sector.

TABLE 1: Water Demand Estimates and Projections (Millions $\mathrm{m}^{3}$ )

\begin{tabular}{lcccc}
\hline \hline Sector & $\mathbf{2 0 0 9}$ & $\mathbf{2 0 1 5}$ & $\mathbf{2 0 2 0}$ & $\mathbf{2 0 3 5}$ \\
\hline \hline Domestic: NWSC & 56 & 85 & 116 & 284 \\
Domestic: Small Towns & 24 & 35 & 47 & 111 \\
Domestic: Rural & 127 & 210 & 306 & 588 \\
Livestock & 107 & 151 & 164 & 211 \\
Crops & 335 & 489 & 452 & 676 \\
Fisheries & 52 & 105 & 157 & 210 \\
Rural Industries & 5 & 19 & 23 & 33 \\
Total water demand & 707 & 994 & $\mathbf{1 , 2 6 6}$ & $\mathbf{2 , 1 1 3}$ \\
Available water Percapita $\left(\mathrm{m}^{3}\right)$ & 2,171 & 1,740 & 1,480 & 896 \\
\hline \hline
\end{tabular}

Notes: NWSC stands for National Water and Sewerage Corporation. This is a Govemment parastatal charged with the supply of commercial water in the country.

Source: MWE(2009)

The role of water as a vital economic resource is not in doubt. However the debate is on the best policy to ensure its efficient use. There are two schools of thought on the economic value of water [Perry et al. (1997)]. One school argues that water should be allocated to its best uses by being priced at its economic value. In addition, it should be allocated through competitive markets. Using the market theory, the value of a commodity is the maximum amount which users are willing to pay for it such that in equilibrium, the marginal cost and marginal benefit are equal [Briscoe (1996) and Perry et al. (1997)]. Another school of thought maintains that water should not be left to market forces because it is a basic human need. However, the current challenges faced by water resources underscore the need to ensure their efficient utilization. In this regard, the current study is motivated by the challenges faced by water resources to argue that water should be utilised in a framework that accounts for its economic value, while still ensuring that it is being equitably accessed.

\section{Institutional Framework for Water Resources Management in Uganda}

The management of water resources is under the Ministry of Water and Environment (MWE). This function is enshrined in the Water Act (Cap 152) of the Constitution of the Republic of Uganda [MWE(2009)]. The MWE is charged with the planning and coordination of all sector activities with the overall mission of "promoting and ensuring the rational and sustainable utilization, development and effective management of water and environmental resources for the socio-economic development of the 
country". The MWE is therefore tasked with setting national policies and standards, managing and regulating water resources and determining priorities for water development and management. It also monitors and evaluates sector development programmes to keep track of their performance, efficiency and effectiveness in service delivery [MWE(2009)]. The Ministry has the following directorates: Directorate of Water Resources Management, Directorate of Water Development (DWD) and the Directorate of Environmental Affairs (DEA). In addition, there are agencies such as National Water and Sewerage Corporation (NWSC) whose role is to supply commercial water. The agency derives its legal mandate from Decree No. 34 of 1972 and later from the National Water and Sewerage Act enshrined in the (1995) Constitution of Uganda. This agency is charged with improving water and sanitation services in the country on a commercially viable basis [NWSC (2011)]. Accordingly:

\section{Using the New Economic Order Model (NEO) which was introduced in 2011 as a planning tool premised on the principle of demand and supply of water, the agency seeks to achieve equilibrium between effective demand for our services by ensuring that the customer is adequately and efficiently served, while ensuring optimization of resources.}

It is clear that the NWSCs model is geared towards ensuring efficiency in the commercial provision of water. In fact, the approach is in line with the existing evidence on the estimated potential welfare gains from improvements in the quality of water service such as reducing variability or interuptions in the water delivery schedule [Olmstead (2010)]. This has been established to be the case for both developing [Baisa et al. (2009)] and industrialized countries [Hensher et al. (2005)]. It is therefore vital that one of the interventions of the NWSC should be to ensure that water pricing is based on supply cost recovery and full economic cost [Letsoaloet al.(2007)].

\section{Literature Review}

In this section, we highlight the existing literature on the double dividend hypothesis. The review is not exhaustive as it is only aimed at indicating the nature of the debate surrounding the double dividend hypothesis [see Shackleton et al. (1993); Goulder (1995); Bosquet (2000); Ekins and Barker (2001); Tol et al. (2008); Schöb (2009); Fullerton et al. (2010) and Katri (2012) among others, for extensive reviews on the subject]. In addition, it is aimed at providing a context for this paper. In the literature, some authors suggest that measures to address changes in the environment should be designed to use policy instruments that raise revenues. This is because the resulting revenues can be used to generate other benefits for the economy. Since Pigou (1920), it has been widely accepted that environmental taxes are efficient instruments for environmental protection. In addition, they are found to be superior to other policy instruments like command and control.

The arguments in favour of taxes on environmental goods have their foundations in the double dividend theory. According to the theory, revenue generated from the imposition of environmental taxes can be used to lower other would be distortionary taxes. In so doing, the economic cost of the environmental tax is lowered thereby resulting into benefits for the economy [see Tullock (1967); Nichols (1984);Terkla (1984); Lee and Misiolek (1986); Van Heerden et al. (2006); Blignaut et al. (2007); Brouwer et al. (2008); Tol et al. (2008); Zhou and Segerson (2012) and Katri (2012) among others]. The major implication of the doubledividend theory is that if there is consensus about an environmental target, revenue-raising instruments are preferred to other 
policy instruments which, although costefficient in regulating the environment, do not raise public revenues [Schöb (2009)]. Realization of the double dividend is in terms of the environment (first dividend) and the economy (second dividend) which are envisaged to improve following the imposition of the tax [Letsoalo et al. (2007)]. Goulder (1995) develops two versions of the double dividend hypothesis: the strong and the weak form of the double dividend. The weak form requires a revenue-neutral environmental tax reform to recycle the additional revenues in order to reduce the economic costs of the tax compared to the case where those revenues are recycled as a lump-sum. On the other hand, the strong form version requires that environmental tax reform to not only yield environmental gains but also non-environmental welfare [Rausch and Reilly (2012)]. Economic analysis demonstrates the potential benefits of recycling revenue from an environmental tax. Specifically, such a tax can be used to offset other taxes thereby reducing the potential cost of the policy. Under certain circumstances, it can boost economic welfare [Goulder (1995) in Rausch and Reilly (2012)]. Howoever, Zhou and Segerson (2012) demonstrate that depending on the size of the tax base, environmental taxes may be efficient instruments for improving environmental quality, but not necessarily a better way to raise revenue.

Several studies use different approaches to check for the existence of the double dividend hypothesis in many different contexts. Bovenberg and De Mooij (1994) use a simple one factor model which assumes competitive markets and find that environmental taxes exacerbate, rather than alleviate the pre-existing tax distortions. Fullerton and Metcalf (1997) and Goulder et al. (1997) show that increasing a narrow-based green tax and reducing a broad-based tax say on labour income would be distortionary. This implies that the revenue-recycling effect may not fully offset the negative effect of the environmental tax on employment. This would be the case even when the revenue is used to reduce the tax rate on labor income. The literature highlights the fact that whereas a strong double dividend is possible, it not may not always be guaranteed. In fact, it depends on a number of factors which among others, include the existing tax rates, elasticities as well as the level of inefficiency of the tax system [see Goulder (1995); Van Heerden et al. (2006); Bento and Jacobsen (2007); Zhou and Segerson (2012) and Katri (2012)]. In the case of an environmental tax that targets water as a factor of production, substitution elasticities between factors are critical. The fixed factor, capital should be a poor substitute for the water, while labor should be a good substitute. With an elastic supply of capital, the converse is true [see De Mooij and Bovenberg, (1998)]. This efficiency gain has to be large enough in order to offset the negative impacts that are inherent in environmental taxes. The broader is the tax base, the lower is the distortion. Goulder (1994) asserts that environmental taxes are usually narrow because they are meant to change specific behavior.

Goulder (1995) and Bovenberg and Goulder (1997) use a general equilibrium model and fail to find evidence of a double dividend. In all their scenarios the environmental tax is found to be more distortionary than the substitute taxes and they attribute this finding to the relative narrowness of the environmental tax. For instance, Goulder (1995) finds that the economic cost of environmental taxes would be in excess of $35 \%$ if the revenues are recycled across the board rather than in a targeted manner to reduce other distortionary taxes. On the other hand, Jorgenson and Wilcoxen (1993) do find a double dividend under certain conditions. Irrespective of the end result, the costs or benefits of the tax reform were found to vary with the scenario chosen. However, they were in line with Goulder (1994) expectations. That is, the lower are the costs, the larger are the differences in 
Marginal Excess Burden (MEB) and the more the tax burden was shifted from the overtaxed to the under-taxed factor. ${ }^{2}$ Zhou and Segerson (2012) utilize the framework by Bovenberg and de Mooij (1994) to assess the viability of using environmental taxes to finance budget deficits in the US state of Connecticut. They find that due to the namowness of the tax base, environmental taxes have limited potential to raise revenue to finance the fiscal deficits and/or reduce other distortionary taxes. Nonetheless, they note that such taxes can still generate significant gains for the economy if they lead to significant improvements in environmental quality.

The analysis of the double dividend hypothesis besides revenue mobilization involves the redistribution of income in the economy. Worth noting is the fact that the process results in the deviation of the tax mechanism from its optimal level. ${ }^{3}$ Therefore, the distributive impacts of environmental tax reform need to be studied in much detail. There are studies which have looked at the distributive component of environmental taxation [see Letsoalo et al. (2007), Chiroleu-Assouline and Fodha (2006); Van Heerden et al. (2006), Blignaut et al. (2008); Tol et al. (2008) and Chiroleu-Assouline and Fodha (2009)]. The findings suggest that the distributional impact of the tax depends on the specific form of the tax reform and how it is implemented. The suggestion of shifting the tax burden to the unemployed or those working in the informal sector to increase employment as is in Bovenberg and VanderPloeg (1998) has the potential to adversely affect income for the lowest income groups.

From the existing literature, it is clear that the double dividend hypothesis has been analyzed using different methodologies, assumptions, and measures. It is therefore not surprising that these studies yield mixed results. For instance, studies in the developed countries tend to find a positive second dividend when employment is used as a benchmark and modest positive or negative effects on output [see e.g., Ekins et al. (2011); Ekins and Barker (2001); Bosquet (2000); Patuelli et al. (2005); Lutz and Meyer (2010) and Moe (2010)]. However Schöb (2009) fails to find evidence of the strong form of the hypothesis in his study of the United Kingdom. Empirical studies in the U.S have found that when revenue from environmental taxes is used to reduce preexisting taxes, the gross cost of the tax system increases, i.e., the strong form of the double dividend hypothesis does not hold [Zhou and Segerson (2012)]. Goulder (1992) finds that welfare is reduced by $0.48 \%$ when the environmental tax is used to reduce the corporate income tax and by $0.53 \%$ when used to reduce the personal income tax. Furthermore, Goulder (1995) reviewed some empirical studies based on different models and found that a tax swap resulted in a welfare loss for most models except the Jorgenson-Wilcoxen model [see Zhou and Segerson(2012)].

For the developing countries, some studies find evidence of the hypothesis in its strong form, but add a caveat that the design and implementation of such interventions is critical. For instance, Van Heerden et al. (2006) use a CGE model to investigate of the plausibility of achieving a double dividend through a tax on water and energy and recycling the revenue back into the economy. They find that it is possible for such interventions to yield double dividends. Other studies with closely similar findings include Decaluwé et al. (1999); Diao and Roe (2003); Bluffstone (2003); Letsoalo et al. (2007) and Blignaut et al. (2008). In fact

\footnotetext{
${ }^{2}$ See Goulder(1994) for athorough exposition on the adjustment mechanism.

${ }^{3}$ In the absence of extemalities it would be optimal to have alump sum tax.
} 
Sartzetakis and Tsigaris (2009) note that environmental tax reform may reduce involuntary unemployment. With regard to equity, such reforms can adversely affect the income distribution, thereby reducing the possibility of achieving a second dividend.

From the literature, it can be concluded that achieving a double dividend from an environmental tax is possible but it is not obvious. The initial conditions in terms of the existing taxes, possible distortions in the labor market, together with the specific nature of the tax intervention are key determinants of the outcome of any such policy measure. Therefore, the design of the tax intervention should clearly be well thought out, with attention being paid to the pre-existing distortions [Letsoalo et al. (2007)]. In fact, interventions that are designed to yield multiple benefits i.e., additional dividends (say poverty reduction) require more detail with respect to their policy design. Spratt (2012) in a scoping study of environment taxation in developing countries concludes that limits to the effectiveness of environmental taxes become more severe as the number of policy goals increase. He asserts that achieving "double dividends" may be hard and triple dividends even much harder.

\section{Methodology}

This study employs the Uganda Applied General Equilibrium (UgAGE) model to evaluate the economy-wide impact of potential water tax scenarios in Uganda. The theoretical structure of UgAGE is based on the ORANI-G model documented in Horridge (2001) with various add-ins to facilitate the detailed modelling of water accounts in the country. In this version of UgAGE, we use an aggregated 13-sector database. The model is implemented in GEMPACK and solved using Euler's multistep solution technique.

Applied or computable general equilibrium models provide industry-level disaggregation in a quantitative description of the whole economy and typically postulate neo-classical production functions and price-responsive demand functions, linked around an input-output matrix in a general equilibrium model that endogenously determines prices and quantities. As required by GEMPACK, an initial levels solution of the model is represented by the base year data. The theory of the model is then, essentially, a set of equations that describe how the values in the model's database move through time and move in response to any given policy shock. For any given exogenous policy shock, the results produced by the model represent changes or percentage changes away from an unperturbed projection of the economy and its structure, represented by the base year data.

Following the ORANI-style of implementing a CGE model, the general equilibrium core of UgAGE is made up of a linearized system of equations describing the theory underlying the behaviour of participants in the economy. It contains equations describing, amongst others: the nature of markets; intermediate demands for inputs to be used in the production of commodities; final demands for goods and services by households; demands for inputs to capital creation and the determination of investment; government demands for commodities; and foreign demand for exported goods.

The specifications in UgAGE recognise each industry as producing one or more commodities, using as inputs combinations of domestic and imported commodities, different types of labour, capital and land. The multi-input, multi-output production specification is kept manageable by a series of separability assumptions. This nested production structure reduces the number of 
estimated parameters required by the model. Optimising equations determining the commodity composition of industry output are derived subject to a CET function, while functions determining industry inputs are determined by a series of nests. At the top level, intermediate commodity composites and a primary-factor composite are combined using a Leontief or fixed-proportions production function. Consequently, they are all demanded in direct proportion to industry output or activity. Each commodity composite is a CES function of a domestic good and its imported equivalent. This incorporates Armington's assumption of imperfect substitutability for goods by place of production [Armington (1969)]. The primary-factor composite is a CES aggregate of composite labour, capital and, in the case of primary sector industries, land. Composite labour demand is itself a CES aggregate of the different types of labour distinguished in the model's database. In UgAGE, all industries share this common production structure, but input proportions and behavioural parameters vary between industries based on available base year data and econometric estimates, respectively. In this regard, the model parameters used in our analysis are derived from the IFPRI model for Uganda [see Dimaranan et al. (2006)] in addition to other relevant studies in the literature [see Hertel et al. (2007); Boysen and Mathews (2012) and Boysen (2012)] and informed by the author's knowledge of the Ugandan economy. Those sets of parameters include: (1) The Armington elasticity between domestic and imported commodities; (2) Export elasticities; (3) Elasticity of substitution among labor types (or skills); (4) Elasticity of substitution among primary factors; (5) CET transformation for industries with multiple commodities; (6) Expenditure elasticity for the LES household demand system; (7) The Frisch parameter (elasticity of marginal utility of income) and (8) The Armington elasticity for investment.

The demand and supply equations in UgAGE are derived from the solutions to the optimisation problems which are assumed to underlie the behaviour of private sector agents in conventional neo-classical microeconomics. Each industry minimises cost subject to given input prices and a constant returns to scale production function. Households maximise a Klein-Rubin utility function subject to their budget constraint. Units of new industry-specific capital are constructed as cost-minimising combinations of domestic and imported commodities. The export demand for any locally produced commodity is inversely related to its foreign-currency price. Government consumption, typically set exogenously or linked to changes in household consumption, and the details of direct and indirect taxation are also recognised in the model. Zero pure profits are assumed for all industries.

The model's database is based on the 2009 Social Accounting Matrix (SAM) for Uganda published by the Uganda Bureau of Statistics (UBOS). In the SAM, households are categorized into 4 regional groups by rural-urban and by income quintiles. In all, there are 39 industries and commodities. However, these were aggregated into 13 sectors to facilitate our analysis. This is in addition to splitting electricity and water into two industries. Water data [DWRM (2012); FAO (2005)] are drawn from the relevant departments under the Ministry of Water and Environment in order to create a vector of taxable water for each industry in the SAM as well as a vector of extra water charges that may be charged on volumes of water. All taxable water is derived from ground and surface water data.

Next, we add a water revenue equation into the UgAGE model to enable us to calculate changes in total revenue raised and changes in water demand. It is derived from the identity that total revenue raised $R$ is equal to the tax rate $T$ per volume times the quantity of water $X$. That is: 
All model equations are expressed in percentage change form. The model is linearized in order to allow for solving. From equation (1), the change in revenue $d R$ is approximately equal to the tax rate $T$ times the change in the base $d X$ plus the base $X$ times the change in the rate $d T$. Formally:

$$
d R=T . d X+X . d T=T . X . x / 100+X . d T=R \cdot x / 100+X . d T
$$

with $x$ being the percentage change in $X$. If $x$ is the percentage change in $X$, then we know that $x=100 * d X / X$, such that $d X=x . X / 100$. Equation (2) is used in our model to calculate the changes in revenue received from charges on water consumption by all industries. The changes in the tax rates are exogenous. In addition, they are shocked according to various scenarios outlined in section 5 . All the other variables are either entered into or they are computed by the model. Note that the variable $x$ is the percentage change in water consumption by industries and it is endogenous. Put differently, $x$ is computed by the model. We expect that an additional charge on water will lead to a decrease in water consumption. Total revenue from the extra water charges will be added to total government revenue.

Furthermore, in order to assess the impact of the proposed policy interventions on industry output, we use the Fan decomposition in order to assess these changes for the different industries following the taxation and plough-back process. This approach uses the market clearing assumption of the model in order to explain changes in industry outputs following a shock [Wittwer and Kym (2001)]. Formally, the percentage change in output is a weighted sum of the percentage changes in sales volumes, decomposed by sales point. Quantitatively, if we denote $D$ as domestic production, $L_{d}$ as local sales of domestic output and $X$ as exports, the market-clearing equation is expressed as:

$$
D d=L_{d} l+X x
$$

The variables $l$ and $x$ are the percentage changes in local sales and exports that contribute to the percentage change in output $d$. Furthermore, we obtain an expression for the change in local sales $\left(l^{*}\right)$ in order to account for the effect of import replacement on domestic output:

$$
L l^{\star}=L_{d} l+M m
$$

Where $L$ is the total quantity of local sales from all sources; $M$ is the level of imports and $m$ is the percentage change in imports. Hence, the modified market-clearing equation becomes: 


$$
D d=L l^{*}+X x-M m
$$

In computing large change solutions, the decomposed components of equation (5) will not add exactly to $D d .{ }^{4}$ To overcome this, we define an ordinary change variable $q$ such that

$$
P D^{0} q=P D d
$$

where $D^{0}$ is the initial quantity of total sales, and $P$ is the price level which is updated during the solution procedure. To decompose total output, let

$$
q=q_{l}+q_{x}+q_{m}
$$

where $q_{l}$ is the local market contribution; $q_{x}$ is the export contribution and $q_{m}$ is the import replacement contribution (each in ordinary change terms) to total output. The local market contribution to the percentage change in domestic production is defined as the percentage change in local sales from local and imported sources, weighted by the value of locally sourced sales. Formally:

$$
q_{l}=\frac{L_{d} l^{*}}{D^{0}}
$$

The export contribution is $q_{x}=\frac{X x}{D^{0}}$. Finally, the import contribution is calculated as aresidual from equation (7).

\section{Policy scenarios}

In this section, we employ different taxation and plough-back scenarios to assess the distributional effects of a water tax. This involves levying a tax and establishing the appropriate channels through which the realized tax revenue can be utilized in order to yield dividends for the economy. The simulation scenarios employed are in line with the policies of the Ministry of Finance Planning and Economic Development of revenue mobilization. Similarly, they are related to the vision of the Ministry of Water and Environment and the water distribution agency (NWSC) of improving water and sanitation services in the country on a commercially viable basis. Whereas the critical policy issues include revenue generation and provision of water at market rates we use simulation scenarios which reflect the fact that issues of access and affordability are equally important. ${ }^{5}$ The charges for some sectors of the economy particularly the households majority of which are poor, should not be at a level where they are left without access to safe water [Spratt (2012)].

\footnotetext{
${ }^{4}$ This is because in multi-step computation, percentage changes are compounded whereas ordinary changes are added.

${ }^{5}$ See e.g., Gowlland-Gualtiei (2007) for a contextualized exposition of how issues of sustainability and equity in the provision of water are implemented in South Africa.
} 
Cognizant of the issues of affordability and access, the following scenarios were simulated using the UgAGE model. A tax of UGX 500 (US\$20cents per $\mathrm{m}^{3}$ ) on water used by the following industries: i) Mining; ii) Manufacturing, iii) Construction; iv) Agriculture; v) Business; vi) Hotels and restaurants; vii) Other services ${ }^{6}$. The choice of sectors was informed by their ability to pay as well as the degree of water use in their production activities. Industries with less water use in their activities were left out. In terms of plough-back, two simulations were performed: a) a decrease in production taxes on capital and labor, b) a decrease in sales taxes. The choice of the plough-back schemes was informed by the fact that the reduction in the level of taxation to factors of production would induce economic activity via production while a sales tax break would drive economic activity via consumption.

\subsection{Policy variables}

Four variables of interest are analyzed in the model. These include changes in: a) water use; b) GDP; c) employment; d) industry output. The variables are expressed in "per unit of government revenue" so that the different policy scenarios are comparable. These variables presented in the next section as changes in water consumption per billion shillings in government revenue; Percentage change in real GDP per billion shillings of revenue collected or ploughed-back; Percentage change in aggregate employment per billion shillings of revenue collected or ploughed-back; and changes in industry output.

\subsection{Model Closure}

In order to analyze the impact of a water tax on water use and the economy as a whole, the effectiveness of such a policy measure has to be assessed on how sustainable it would be with respect to the use of water resources. In this regard, the model closure rules have been set to account for policy sustainability using the long-run time horizon. ${ }^{7}$ Results from the policy measures for both long-run and short-run closures are presented in section 6. Under the short run closure conditions, capital stock in each sector is exogenous, while the rates of retum on capital, aggregate employment and trade balance are endogenous. The trade balance is set to be endogenous because it is possible for the economy to run a deficit on the extemal sector in the short run. In addition, aggregate investment, the composites of GDP from the expenditure side (private and public consumption), real wage rate, all technological change variables and all tax rates inventories are exogenous.

\footnotetext{
${ }^{6}$ Includes waterused by households.

${ }^{7}$ SeeDixonetal.,(1982) and Bohlmann(2011)for a thorough description of the technical details behind the stucture of CGE models.
} 


\section{Results and discussion}

\subsection{Macroeconomic level results}

Table 2 presents a summary of the macroeconomic level results from the tax simulations and recycling schemes. The analytical process evolves as follows: when a tax is levied, (i) taxes increase the cost of production and therefore decrease the supply of most commodities, while (ii) the increase in government revenue without a concomitant increase in govemment expenditure decreases aggregate demand. Since both capital and skilled labour face inelastic supply in the short-run, the fall in aggregate demand causes a significant reduction in price levels and a decline in real GDP. The increase in domestic prices leads to a decline in exports of most commodities and an increase in imports. The recycling schemes work in the opposite direction.

TABLE2: Results of Key variables (Percentage changes)

\begin{tabular}{|c|c|c|c|}
\hline \multicolumn{2}{|c|}{ 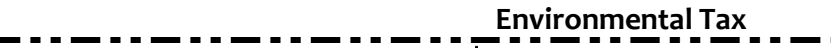 } & \multicolumn{2}{|l|}{ Recycling scheme. } \\
\hline Variables & Water tax & Sales tax & Production tax \\
\hline Real GDP & -0.153 & 0.11 & 0.16 \\
\hline Imports & 0.111 & 0.042 & -0.18 \\
\hline Exports & -0.509 & 0.533 & 0.447 \\
\hline Investment & 0 & 0 & 0 \\
\hline Import prices & 0 & 0 & 0 \\
\hline Government expenditure & 0 & 0 & 0 \\
\hline GDP deflator & 0.458 & -0.613 & -0.472 \\
\hline Investment price index & 0.343 & -0.642 & -0.556 \\
\hline Consumer price index & 0.326 & -0.433 & -0.292 \\
\hline Export price index & 0.348 & -0.406 & -0.358 \\
\hline Government price index & 0.546 & -0.491 & -0.452 \\
\hline Nominal exchange rate & 0 & 0 & 0 \\
\hline Aggregate primary factor use & -0.167 & 0.115 & 0.163 \\
\hline Intermediate prices & & & $-\ldots$ \\
\hline Agriculture & 0.333 & $-0 . \overline{36}$ & -0.189 \\
\hline Mining & 0.075 & -0.396 & -0.094 \\
\hline Manufacturing & 0.239 & -0.384 & -0.174 \\
\hline Electricity & 0.06 & -0.391 & -0.072 \\
\hline Water & 0.048 & -0.346 & -0.041 \\
\hline Construction & 0.094 & -0.43 & -0.193 \\
\hline Trade & 0.092 & -0.331 & -0.1 \\
\hline Hospitality & 0.249 & -0.355 & -0.177 \\
\hline Transport & 0.056 & -0.348 & -0.048 \\
\hline Post and Telecommunication & 0.118 & 0.118 & -0.128 \\
\hline Business & 0.158 & -0.424 & -0.194 \\
\hline General Government & 0.314 & -0436 & -0.128 \\
\hline Other Services & 0.215 & -0.437 & -0.204 \\
\hline Industry Output & $=-$ & & $\ldots$ \\
\hline Agriculture & -0.29 & 0.127 & 0.162 \\
\hline Mining & -0.392 & 0.078 & 0.098 \\
\hline Manufacturing & -0.073 & 0.197 & 0.442 \\
\hline Electricity & -0.051 & 0.063 & 0.054 \\
\hline Water & 0.001 & -0.001 & 0.001 \\
\hline Construction & -0.006 & 0.007 & 0.011 \\
\hline Trade & -0.048 & 0.1 & 0.133 \\
\hline Hospitality & -0.575 & 0.475 & 0.527 \\
\hline Transport & -0.088 & 0.078 & 0.076 \\
\hline Post and Telecommunication & -0.083 & 0.05 & 0.044 \\
\hline Business & -0.025 & 0.035 & 0.062 \\
\hline General Government & -0.082 & 0.059 & 0.037 \\
\hline Other Services & -0.307 & 0.138 & 0.238 \\
\hline
\end{tabular}

Source: Author's computations 


\subsection{Environmental effects}

In analyzing the environmental effects of the tax (first dividend), changes in water use are divided by changes per unit of tax revenues in real terms. The results are presented in Table 3 where a tax reduces water use, implying that for all the simulations, changes in water use following a tax yield the first dividend for the different industries. In addition, both recycling schemes yield an environmental dividend. This implies that the environmental benefits associated with the reduction in water use are realized irrespective of the channel through which the collected revenue is ploughed back into the economy. Essentially, the first dividend is confirmed to exist under the recycling schemes only if there is a net reduction in the amount of water used per unit of real government revenue recycled. From the results, we see that a tax on water consumption always leads to a decrease in water use (Table 3, column 2). Whereas water consumption increases following the revenue recycling process, this increase is less than the initial decrease in water use following the tax (columns $3 \& 4$ ).

TABLE 3 : Marginal changes in Water Consumption from Imposition and Recycling of a Tax

\begin{tabular}{|c|c|c|c|}
\hline \multicolumn{2}{|l|}{ Water Tax } & Sales tax Break & Production tax Break \\
\hline \multicolumn{2}{|c|}{ Reduction in water consumption } & \multicolumn{2}{|c|}{ Increase in water consumption } \\
\hline Industry & & 0.00141 & 0.00189 \\
\hline Agriculture & -0.0201 & + & + \\
\hline Mining & -0.0214 & + & + \\
\hline Manufacturing & -0.0203 & + & + \\
\hline Construction & -0.0207 & + & + \\
\hline Hospitality & -0.0110 & + & + \\
\hline Business & -0.0096 & + & + \\
\hline Other Services & -0.0134 & + & + \\
\hline
\end{tabular}

Notes: The results in column 2 are percentage decreases in water use per UGX1 billion in tax revenue raised. Under the recycling scheme (column 3 and 4 ), the result 0.00141 and 0.00189 are the average increases in water use for the respective schemes. If the increase in water use which follows the recycling is less than the initial decrease following the tax, the net effect is a decline in wateruse and hence aplus (+) sign to signify an environmental dividend.

Source: Author's computations

In Table 3, we see that the reduction in water use as a result of a tax is greater than the increase in water consumption following the revenue recycling schemes. Therefore, an environmental dividend is realized from this tax and recycling schemes. From the table, a tax on agriculture results in a decrease in water consumption by the sector of $0.0201 \%$ per UGX1 billion of realized tax revenue. All changes in water consumption are expressed in terms of percentage changes per UGX1 billion of revenue collected. On the other hand, a sales or production tax break through recycling increases economic activity, and more water is consumed. For example, a sales tax break increases water consumption by $0.00141 \%$ on average per industry for each UGX1 billion in recycled tax revenue. A combination of a tax on agriculture and a sales tax break involving the same amount of revenue, results in a net decrease in water demand. ${ }^{8}$

\footnotetext{
${ }^{8}$ Due consideration was taken in the choice of water demand semi-elasticities used as they are fundamental in influencing the results. Different elasticities were tested over a wide range and there was no significant change in results for the variables of interest.
} 


\subsection{Economic effects}

GDP and employment effects

In order to assess the economic impact of the tax on the economy, we compute the Marginal excess burden (MEB). The marginal excess burden (MEB) is the change in real GDP divided by the change in real government revenue. In this case, we analyze how GDP declines as a result of an increase in total tax revenue. On the other hand we also assess the impact on GDP of a tax break through the two recycling schemes. In this case, the MEB measures the increase in GDP per decrease in total tax revenues. Formally:

\section{$M E B=$ change in real $G D P /$ change in real government income}

The MEB is a proxy for the distortion which arises from the imposition of a tax. Given that the numerator and denominator are measured in monetary terms, comparing the MEBs for the different scenarios gives combinations of scenarios which produce a second dividend, i.e., an increase in GDP while maintaining total government revenue constant.

TABLE 4 : Marginal Excess Burden from the imposition and Recycling of a Tax

\begin{tabular}{l|c|c|c}
\hline \multicolumn{2}{c}{ Water tax } & \multicolumn{2}{c}{ Increase in GDP } \\
\hline \hline Marginal Excess Burden & Sales tax Break & Production tax Break \\
\hline Industry & -0.00655 & - & - \\
\hline Agriculture & -0.00018 & + & + \\
Mining & -0.00034 & + & + \\
Manufacturing & -0.00076 & + & + \\
Construction & -0.0013 & - & + \\
Hospitality & -0.00098 & + & + \\
Business & -0.00284 & - & - \\
Other Services & - & + & + \\
\hline \hline
\end{tabular}

Notes: Theresults in column 2 are percentage decreases in real GDP perUGX1billion in tax revenue collected. Under the recycling scheme (column 3 and4), the result 0.0011 and 0.0016 are the average increases in real GDP for the respective schemes. If the increase in real GDP following recycling is more than the initial decrease which follows the tax, the net effect is an increase in real GDP and hencea plus sign to signify an economic dividend.

Source: Author's computations

The MEBs for all seven water tax policy measures as well as the two recycling measures are compared in Table 4. Column 2 presents the losses in GDP that accrue to the different industries following the imposition of a tax. A double dividend is indicated by a plus (+) sign. This implies that the increase in real GDP per unit of real govemment revenue lost as a result of a tax break is larger than the decrease in real GDP per unit of real government revenue collected from the tax for the respective industries. Otherwise, a minus (-) sign is indicated. Fromour computation, the results in Table 4 are interpreted as follows: When a water tax is levied on the agriculture industry and UGX1billion is realized in tax revenue, real GDP decreases by UGX6.5 million. Similarly, the MEBs are computed for the recycling schemes producing values of 0.0011 and 0.0016 for the sales and production tax breaks respectively. From the results, a combination of a water tax on agriculture and both sales and production tax breaks result in a decrease in real GDP. The results show that a tax on water for agriculture and other services ${ }^{9}$ would be distortionary to the economy because the net effect on GDP is negative despite the recycling schemes. Similarly, taxing the hospitality industry and recycling using a sales tax break would not yield a dividend. However, for the rest of the industries, a tax followed by

\footnotetext{
${ }^{9}$ Household consumption is accounted for under thisindustry.
} 
recycling yields a double dividend for the economy. In Table 5, we present results of the percentage changes in aggregate employment per unit of govemment revenue were.

TABLE 5: Marginal changes in employment fromimposition and recycling of a Tax

\begin{tabular}{l|c|c|c}
\hline \multicolumn{2}{c}{ Water Tax } & \multicolumn{2}{c}{ Recycling Scheme } \\
\hline \hline Marginal change in employment & Sales tax Break & Production tax Break \\
\hline Industry & -0.00087 & 0.000237 & 0.00033 \\
\hline Agriculture & -0.00187 & - & - \\
Mining & -0.00019 & - & - \\
Manufacturing & -0.000012 & + & + \\
Construction & -0.00073 & + & + \\
Hospitality & -0.00017 & + & + \\
Business & -0.00037 & + & - \\
Other Services & (1) & + & + \\
\hline \hline
\end{tabular}

Notes: Theresults in column 2 are percentage decreases in employment per UGX1billionin tax revenue collected. Under the recycling scheme(column 3 and4), the result 0.000237 and 0.00033 are the average increases in employment for the respective schemes. If the increase in employment following recycling is more than itsinitial decrease following the tax, the net effect is an increase in employment and hence a plus sign to signify an economic dividend.

Source: Author's computations

Generally, employment is closely linked to GDP. In this study however, the results of the percentage changes in employment per billion of tax revenue follow a slightly different trend from that of the MEB results in Table 4 for the mining, hospitality and other services industries. From Table 5, a double dividend is realized for taxes to certain industries as well as for certain recycling schemes. For instance, a water tax on the agriculture and mining industries would be distortionary, even when the taxes are recycled using either scheme. The production tax break proves better in correcting the distortion with respect to GDP performance compared to the sales tax break and the converse is true with respect to employment. Note however that the differences in performance of the tax and recycling scheme emanate from utmost two industries in both cases.

\subsection{Fan Decomposition analysis of the changes in Industry output}

Table 6 presents the results of the impact of the tax on industry output. If we take the agriculture industry as an illustration, we show that the predicted changes in domestic output from the agriculture industry are derived from three effects:

i) The local market effect. i.e., an increase in domestic demand for agricultural output whether domestically-produced or imported;

ii) The domestic share effect. i.e., a shift in local usage of agricultural output from the imported to the domestically produced; or

iii) The export effect. i.e., an increase in the export of agricultural output.

In most cases, these effects tend to work in different directions. For instance, a water tax increases the cost of production which induces a decrease in foreign demand. As a result, local producers cut down on the level of supply thereby increasing the domestic price and facilitating import penetration. The essence of the Fan decomposition ${ }^{10}$ is to show the relative magnitudes of these three contributions to output change. Table 6 presents the results of changes in total industry output following a tax and recycling

\footnotetext{
${ }^{10}$ Named after Fan Ming-Tai of the Academy of Social Sciences, Beijing Institute of Quantitative and Technical Economics.
} 
schemes for all industries analyzed in the model. In order to provide a more detailed analysis of the decomposition, Table 7 gives a breakdown of the changes in shares in total industry output for some selected industries.

TABLE 6: Effect of a Water Tax and Recycling on Total Industry output

\begin{tabular}{|c|c|c|c|}
\hline Sector & Water tax & Sales tax Break & Production tax Break \\
\hline \multicolumn{4}{|l|}{ Category: Taxed } \\
\hline Agriculture & -0.289 & 0.127 & 0.162 \\
\hline Mining & -0.377 & 0.085 & 0.114 \\
\hline Manufacturing & -0.081 & 0.196 & 0.435 \\
\hline Construction & -0.006 & 0.008 & 0.013 \\
\hline Hospitality & -0.546 & 0.45 & 0.5 \\
\hline Business & -0.037 & 0.044 & 0.072 \\
\hline Other services & -0.262 & 0.128 & 0.209 \\
\hline \multicolumn{4}{|l|}{ Category: Non-taxed } \\
\hline Electricity & -0.051 & 0.062 & 0.054 \\
\hline Water & 0.001 & -0.002 & 0.001 \\
\hline Trade & -0.061 & 0.099 & 0.147 \\
\hline Transport & -0.088 & 0.079 & 0.077 \\
\hline Post and Telecomms & -0.088 & 0.05 & 0.049 \\
\hline General Government & -0.086 & 0.059 & 0.04 \\
\hline
\end{tabular}

Notes: Theresults are percentage changes in total industry output following the taxation and recycling process.

Source: Author's computations

From Table 6, a tax induces a larger reduction in output for the taxed industries than the non-taxed. Nonetheless, the effects of the policy are felt across the economy. Similarly, the recycling schemes show an improvement in output for most of the industries. However, for the taxed industries, agriculture, mining, hospitality and other services registered a much more increase in output from the recycling scheme than the initial decline that followed the tax. This was seen to be the case for general government and transport among those in the non-taxed industries category.

TABLE 7:Effect of a Water Tax and Recycling on the shares of Industry output

\begin{tabular}{|c|c|c|c|c|}
\hline Industry & Local Market & Domestic share & Export & Total \\
\hline \multicolumn{5}{|c|}{ Senario 1: Water Tax } \\
\hline Agriculture & -0.085 & -0.029 & -0.175 & -0.289 \\
\hline Mining & 0.005 & -0.157 & -0.225 & -0.377 \\
\hline Manufacturing & 0.026 & -0.063 & -0.044 & -0.081 \\
\hline \multicolumn{5}{|c|}{ Scenario 2: Sales Tax Break } \\
\hline Agriculture & 0.021 & -0.011 & 0.117 & 0.127 \\
\hline Mining & 0.019 & -0.062 & 0.128 & 0.085 \\
\hline Manufacturing & 0.029 & 0.014 & 0.153 & 0.196 \\
\hline \multicolumn{5}{|c|}{ Scenario 3: Production Tax Break } \\
\hline Agriculture & 0.084 & 0.002 & 0.076 & 0.162 \\
\hline Mining & 0.032 & 0.049 & 0.034 & 0.114 \\
\hline Manufacturing & 0.03 & 0.266 & 0.139 & 0.435 \\
\hline
\end{tabular}

The percentage change in local sales is derived from both foreign and domestic sources. The local market component of the percentage change in domestic production is weighted by the value of local domestic sales. The domestic share component is calculated as a residual [See Homidge (2000)]. ${ }^{11}$

Source: Author's computations

${ }^{11}$ No interactive termis concealed in the residual. Because these decompositions are specified in small change terms, the changes due to each part add up to the change in the whole. 
For the selected industries, the local market contribution explains only part of the proportional reduction in output in the first scenario. For agriculture, this contribution is 0.085 percent out of the total decrease in output of 0.29 percent. For mining, the contribution increases by 0.05 percent out of 0.38 per cent while for manufacturing, it increases by 0.026 percent. In terms of a shift from the usage of local output from imported to domestic, we see that the tax induces a decline in the usage of local output, thereby increasing the amount of imported output. In addition, there is a decline in exports with mining, recording the highest drop. The sales tax recycling scheme shows an increase in the local market share of output for all industries, with exports accounting for the largest share of changes in industry output. A comparison of the two recycling schemes indicates that the production tax break induces a higher increase in industry output than the sales tax. We see that a combination of local market share and export contributes to the overall increase in industry output.

\section{Conclusion}

The study set out to explore the possibility of using a water tax to generate positive effects for the environment and the economy. Given the limited use of environmental taxes in environmental regulation and fiscal policy, the results demonstrate issues which are vital for policy decision making. This is given the fact that environmental resources are experiencing challenges, most of which emanate from economic and human activity. This calls for the need to institute measures to regulate such activities in a sustainable manner. Similarly, as policy makers seek to find ways of widening the tax base, it is important to investigate the viability of using environmental taxes for purposes of domestic resource mobilizations which this study has undertaken.

A tax of US\$20 cents was used in this study because the objective was to assess whether a water tax can yield dividends in a developing country context. Different tax rates were tested and the results proved to be highly sensitive to the tax rates used. Overall, the results show that it is actually possible to generate positive dividends for the economy. However, the realization of any dividends depends upon the sectors on which the tax is charged, the rate of taxation and the choice of recycling scheme. For instance, some studies charge specific sectors as is the case with this study. However, the recycling is usually done across the board. In this study, simulations which involved revenue recycling across the board did not yield any dividends. This implies that only a deeper understanding of a given economy and careful policy design can lead to the realization of dividends from environmental taxation. Whereas the dividend hypothesis asserts that there are gains that accrue from environmental taxation, there is no guarantee that this bound to occur and most importantly, results cannot be generalized across economies.

The relevance of the study goes beyond environmental taxation in Uganda in that it can be extended to other developing economies whose use of environmental tax instruments is still limited and yet these economies stand to suffer from the adverse effects that may arise from environmental mismanagement. Given that water resources constitute only one of the multiple environmental problems being faced globally, the need to utilize environmental tax instruments for purposes of economic and environmental management especially in the developing countries cannot be over emphasized. 
The key policy recommendation that since there is evidence suggesting the potential for generation of dividends , developing economies can utilize this intervention in order to widen their tax base, reduce existing distortionary taxes and engender environmental conservation. However, any positive outcomes can only be realized under certain conditions and are largely dependent upon design of the intervention as well as the conditions prevailing in the economy in question. This implies that a different analytical set up may yield dividends from a different choice of industries and tax policies from the ones which have been identified and tested in this paper. In this study, we focused on establishing whether or not in a developing economy, it is possible to generate revenue, reduce water consumption and increase economic growth, and employment all at the same time. The findings show that depending on the set up, it actually is. 


\section{References}

Alcamo, J., Henrichs, T., and Rösch, T., (2000). World water in 2025: Global modelling and scenario analysis for the World Commission on Water for the 21st Century. Report A0002. Center for Environmental Systems Research, University of Kassel, Kassel, Germany.

Allan, J.A., and Olmsted, J.C., (2003). Politics, economics and (virtual) water. A discursive analysis of water policies in the Middle East and North Africa. In: Lofgren, H. (Ed.), Food and Agriculture in the Middle East and North Africa. JAI/Elsevier, Amsterdam, pp. 53-78(Chapter 5).

Armington, P.S., (1969). A Theory of Demand for Products Distinguished by Place of Production. IMF Staff Papers, 16:159-78.

Baisa, B., Lucas, W.D., Salant, S.W., and Wilcox, W., (2009). The welfare costs of unreliable water service. Joumal of DevelopmentEconomics.

Bates, B.C., Kundzewicz, ZW., Wu, S., and Palutikof, J.PEds.,(2008). Climate Change and Water. Technical Paper for the Intergovernmental Panel on Climate Change, IPCC Secretariat, Geneva.

Bautista, R., Thomas, M., Muir-Leresche, K., and Lofgren, H., (2002). Macroeconomic policy reforms and agriculture: Towards equitable growth in Zimbabwe. Research Report 128, International Food Policy Research Institute, Washington DC.

Bento, A.M., and Jacobsen, M., (2007). Ricardian rents, environmental policy and the 'double-dividend' hypothesis. J. Environ. Econ. Manag. 2007,53, 17-31.

Berrittella, M., Hoekstra, A.Y., Rehdanz, K., Roson, R., and Tol, R., (2007). The economic impact of restricted water supply: A computable general equilibriumanalysis. Water Research, 41(8), 1799-1813. doi: 10.1016j.watres.2007.01.010.

Blignaut, J., Van Heerden, J.H., and Horridge, M., (2008). "Integrated water and economic modelling of the impacts of water market instruments on the South African economy,"Ecological Economics, Elsevier, vol. 66(1), pages 105-116, May.

Bluffstone, R.A., (2003)."Environmental Taxes in Developing and Transition Economies." Public Finance and Management, $3(1), 143-175$.

Bohlmann, H.R., (2011) Labour and Migration Policy in South Africa. A thesis submitted in fulfilment of the requirements for the degree of Doctor of Philosophy, Centre of Policy Studies-Faculty of Business and Economics Monash University.

Bosquet, B., (2000). Environmental tax reform: Does it work? A survey of the empirical evidence. Ecol. Econ.34, 19-32.

Bovenberg, A. L., and Goulder, L.H., (1997). Costs of environmentally motivated taxes in the presence of other taxes: General equilibrium analyses, Natl. Tax J., 50(1), 59-87.

Bovenberg, A.L., and Van der Ploeg, F., (1998). Tax reform, structural unemployment and the environment, Scand. J. Econ., 100(3), 593-610.

Bovenberg, A.L., and De Mooij, R.A., (1994). Environmental levies and distortionary taxation. Am. Econ. Rev. 84, 1085-1089.

Boysen, O., and Mathews, A., (2012). Impact of EU Common Agricultural Policy reform on Uganda. [On-line]. Available at: http//www.odi.org.uk/sites/odi.org.uk/files/odi-assets/publications-opinion-files/7889.pdf [Accessed on 16 ${ }^{\mathrm{h}}$ Nov 2013].

Boysen, O., (2012). A Food Demand System Estimation for Uganda, Discussion Paper 396. Dublin: Institute for International Integration Studies, Trinity College-Dublin.

Briscoe, J., (1996). Water as an Economic good: The Idea and What it means in Practice, World Bank Country Office-Cairo. A paper presented at the World Congress of the Intemational Commission on Irrigation and Drainage. 
Brouwer, R., Hofkes, M., and Linderhof, V., (2008). General equilibrium modelling of the direct and indirect economic impacts of water quality improvements in the Netherlands at national and river basin scale. Ecological Economics Special Issue Integrated Hydro-Economic Modelling.

Calzadilla, A., Rehdanz, K., and Tol, R., (2010). The economic impact of more sustainable water use in agriculture: A computable general equilibrium analysis. Joumal of Hydrology, 384, 292-305.

Calzadilla, A., Rehdanz, K.,Tol, R., (2008). Water scarcity and the impact of improved irigation management: ACGE analysis. Kiel Working Paper No. 1436|July 2008.

Carter, R.C., and Parker, A., (2009). Climate change, population trends and groundwater in Africa. Hydrological Sci J 54: 676689. doi: 10.1623/hysj.54.4.676.

Chiroleu-Assouline, M., and Fodha, M., (2006).Double Dividend Hypothesis, Golden Rule and Welfare Distribution, Journal of Environmental Economics and Management, 51(3), 323-335. doi:10.1016/j.jeem.2005.09.007.

Chiroleu-Assouline, M., and Fodha, M., (2009). Environmental tax and the distribution of income with heterogeneous workers. [On-line] Available at: http://www.parisschoolofeconomics.eu/IMG/pdf/Mouez.pdf.[Accessed on: 22 February 2014].

Chumi, S., and Dudu, H., (2008). Economics of Irrigation Water Management: A literature survey with focus on partial and general equilibrium models, Policy Research Working Paper No. 4556, World Bank, Washington DC.

Deaton, A., and Muellbauer, J., (1980). Economics and Consumer Behavior. Cambridge University Press.

De Fraiture, C., Ximing, C., Amarasinghe, U., Rosegrant, M., and Molden, D., (2004). Does international cereal trade save water? The impact of virtual water trade on global water use. Comprehensive Assessment Research Report 4. Colombo, Sri Lanka: International Water Management Institute.

De Mooij, R. A., and Bovenberg, A.L., (1998). Environmental taxes, intemational capital mobility and inefficient tax systems: Tax burden vs. tax shifting, Int. Tax Public Finance, 5(1), 7-39.

Decaluwe', B., Patry, A., and Savard, L., (1999). When water is no longer heaven sent: Comparative pricing analysis in a AGE model, Working Paper 9908, CREFA99-05, Départment d'e'conomique, Universite' Laval.

Delgado, C., Hopkins, J., and Kelly, V.A., (1998). Agricultural growth linkages in Sub-Sahara Africa. Research Report 107, Intemational Food Policy Research Institute, Washington DC.

Diao, X., and Roe, T., (2003). Can a water market avert the "doublewhammy" of trade reform and lead to a "win-win" outcome? J. Environ. Econ. Manage. 45, 708-723.

Dimaranan, B.V., McDougall, R.A., and Hettel, T.W., (2006). Behavioural Parameters, in Betina, V and Dimaranan (eds) Global Trade Assistance and Producton: The GTAP 6 Data base. Lafayette, IN: Centre for Global Trade Analysis, Purdue University.

Dinar, A., and Yaron, D., (1992). Adoption and Abandonment of Imigation Technologies. Agricultural Economics 6315-32.

Dixon,P.B.,Parmenter, B.R., Sutton, J., Vincent, D.P, (1982). ORANI: A Multi-sectoral Model of the Australian Economy. North-Holland, Amsterdam.

Duchin, F., (1992). Industrial input-output analysis: implications for industrial ecology, Proceedings of the National Academy of Sciences, Vol. 89: 851-855. 
DWRM., (2011). National Water Resources Assessment Draft Report. Directorate of Water Resources Management, Ministry of Water and Environment-Govemment of Uganda.

DWRM., (2012). Various Databases. Ministry of Water and Environment-Govemment of Uganda.

EEA., (2011). Environmental tax reform in Europe: Implications for income distribution, European Environmental Agency, Technical report No: 16/2011.

Ekins,P., and Barker, T., (2001). Carbon taxes and carbon emissions trading, J. Econ. Surv., 15(3), 325-376.

Ekins, P., Summerton, P., Thoung, C., and Lee, D.,(2011). A major environmental tax reform for the UK: Results for the economy, employment and the environment. Environ. Resour. Econ. 50,447-474.

Faust, A., Gonseth, C., and Vielle, M., (2012). The economic impact of climate driven changes in water availability in Switzerland. Research group on the Economics and Management of the Environment-(reme.ep.ch): Working paper.

FEWSNET., (2012). A Climate Trend Analysis of Uganda, Famine Early Warning Systems Network. [On-line] Available from: http//pubs.usgs.gov/fs/2012/3062/FS2012-3062.pdf. [Accessed: 25th April 2013 at21:49 CET].

Fewtrell, L., Kaufmann, R.B., Kay, D., Enanoria, W., Haller, L., and Colford, J.M., (2005). Water, sanitation, and hygiene interventions to reduce diarhoea in less developed countries: a systematic review and meta-analysis. Lancet Infect Dis 5: 42-52. doi: 10.1016/S1473-3099(04)01253-8.

FAO., (2005). Global Information System on Water and Agriculture . Food and Agriculture Organization of the United Nations (FAO)-AQUASTAT., [On-line] Available from: http:/www.fao.org/nr/aquastatt. [Accessed: 22ndFeb 2013 at 08:07 CET] .

Foster, D., and Chilton, PJ., (2003). Groundwater: the processes and global significance of aquifer degradation. Phil Trans R Soc Lond B 258: 1957-72. doi: 10.1098/1stb.2003.1380.

Fullerton, D., Leicester, A., and Smith, S., (2008). Environmental Taxes, Prepared for the Report of a Commission on Reforming the Tax System for the 21st Century, Chaired by Sir James Mirrlees. [On-line]. Availiable at: http://www.ifs.org.uk/mirleesreview/reportsenvironment.pdf.

Fullerton, D., and Metcalf, G.E., (1997). Environmental taxes and the double dividend hypothesis: did you really expect something for nothing? Working Paper No. w6199, National Bureau of Economic Research (NBER). Available at www.nber.org.

Fulletton, D., Leicester, A., and Smith, S., (2010). Environmental Taxes, In Dimensions of Tax Design; Oxford University Press: Oxford, UK, 2010.

Galiani, S. Gertler, P and Schargrodsky, E., (2005). Water for life: The impact of the privatization of water services on child mortality. Joumal of Political Economy 113: 83-120.

Gómez, C.M., Tirado, D., and Rey-Maquieira, J., (2004). Water exchange versus water work: insights from a computable general equilibrium model for the Balearic Islands. Water Resour. Res. 42, W10502, 10.1029/2004WR003235.

Goodman, DJ., (2000). More reservoir or transfer? A computable general equilibrium analysis of projected water shortages in the Arkansas River Basin. J. Agric. Resour.Econ. 25 (2), 698-713.

Gopalakrishnan, C., and Cox, LJ., (2003). “Water Consumption by the Visitor Industry: The Case of Hawaii,” Water Resources Development 19(1):29-35.

Goulder, L.H., Parry, H., and Burtraw, D., (1997). Revenue-raising versus other approaches to environmental protection: the critical significance of pre-existing tax distortions. The RAND Journal of Economics, 28(4): 708-731. 
Goulder, L.H., (1994). Environmental taxation and the “double dividend”: A reader's guide, NBER Working Papers, no w4896.

Goulder, L.H., (1995). Effects of carbon taxes in an economy with prior distortions: An inter-temporal general equilibrium analysis. J.Environ. Econ. Manag., 29, 271-297.

Goulder, L.H., (1992). Do the costs of a carbon tax vanish when interactions with other taxes are accounted for?; Working Paper No.4061; U.S. National Bureau of Economic Research:

Cambridge, MA, USA,

Gowlland-Gualtieri, A., (2007). South Africa's Water Law and Policy Framework Implication to the Right to Water. IELRC Working Paper 2007-03, Geneva: Intemational Environmental Law Research Centre.

Grey, D., and Sadoff, C., (2007). Sink or swim? Water security for growth and development. Water Policy 9: 545-571.

Haller,L., Hutton, G., Bartram, J., (2007). Estimating the costs and benefits of water and sanitation improvements at global level. J Water Health 5: 467-480. doi: 10.2166/wh.2007.008.

Hanjra, M.A., Gichuki, F., (2008). Investments in agricultural water management for poverty reduction in Africa: case studies of Limpopo, Nile and Voltariver basins. Natural Resources Forum32: 185-202. doi: 10.1111/j.1477-8947.2008.00191.x.

Hassan R.M.,and Olbrich, B., (1999). Comparative analysis of the economic efficiency of water use by plantation forestry and irrigation agriculture in the Crocodile River catchment, Agrekon 38(4):566-575.

Hensher, D., Shore, N., and Train, K., (2005). Households' willingness to pay for water service attributes. Environmental and ResourceEconomics 32:509-31.

Hertel, T., Hummel, D., and Keeney, R., (2007). How confident Can we e of CGE-Based Assessments of Free Trade Agreements?, Economic Modelling, 24(4) pp: 611-635.

Horridge, J.M., (2000). ORANI-G: A General Equilibrium Model of the Australian Economy, CoPS/IMPACT Working Paper Number OP-93, Centre of Policy Studies, Monash University, downloadable from: http:/www.monash.edu.au/policy/elecpapr/op-93.htm.

Horidge, J.M., (2001). ORANI-G: A Generic Single-Country Computable General Equilibrium Model. Practical GE Modelling course 18-22:2001. Centre of Policy Studies, Monash University.

Hunter, P.R., MacDonald, A.M., and Carter, R.C., (2010). Water Supply and Health. PLoS Med 7(11): e1000361. doi:10.1371/journal.pmed.1000361.

IPCC.,(2001). Impacts, adaptation, and vulnerability. Contribution of Working Group II to the Third Assessment Report of the Intergovemmental Panel on Climate Change Edited by McCarthy, J., Canziani, O., Leary, N., Dokken, D. and White, K., Cambridge University Press, Cambridge.

Jorgenson, D.W., and Wilcoxen, PJ.,,(1993). Reducing U.S. carbon emissions: An econometric general equilibrium assessment. Resour. Energy Econ., 15, 7-25.

Juana, J.S., and Mabugu, R., (2005). Assessment of small-holder Agriculture's contribution to the economy of Zimbabwe: A Social Accounting Matrix Multiplier Analysis, Agrekon, 44 (3) 344-362.

Katri, K., (2012). "Regressivity in environmental taxation: Myth or reality?" in J.Milne and M.S. Andersen (eds), Handbook of Research on Environmental Taxation, Cheltenham: EdwardElgar. 
Kemp, S.J., MacDonald A.M., and Davies, J., (2005). Transmissivity variations from mudstones. Ground Water 34: 259-69. doi: 10.1111/j.1745-6584.2005.0020.x.

Lee, D.R., and Misiolek, W.S., (1986). "Substituting Pollution Taxation for General Taxation: Some Implications for Efficiency in Pollution Taxation”, Joumal ofEnvironmental Economics and Management 13, 338-347.

Leontaritis, LJ., and Billings, S.A., (1985). Input-Output Parametric Models for Non-Linear Systems. Part I and Part 11. Int. J. Control,41(2),pp. 304-344.

Letsoalo, A., Blignaut, J., de Wit, M., Hess, S., and Tol, R., (2007).Triple Dividends of Water Consumption Charges in South Africa, Water Resources Research, 43 (5): 1-32. [On-line]. Available at: http://citeseerx.ist.psu.edu/viewdoc/download?doi=10.1.1.175.5992\&rep=rep1\&type=pdf.

Lutz, C., and Meyer, B., (2010). Environmental tax reform in the European Union: Impact on CO2 emissions and the economy. Z Energiewirtsch. 2010,34, 1-10.

MacDonald A.M., Davies J, Calow ,RC., Chilton, PJ .,(2005) .Developing groundwater. a guide for rural water supply. Rugby (UK): ITDGPublishing.

MacDonald, A.M., and Calow, R.C., (2009). Developing groundwater for secure rural water supplies in Africa. Desalination 248: 546-556. doi: 10.1016/j.desal.2008.05.100.

Mathew, B., (2005). Ensuring sustained beneficial outcomes for water and sanitation programmes in the developing world. Den Haag (Netherlands): IRC International Water and Sanitation Centre.

MFPED., (2011). Background to the Budget for the 2011/12 Fiscal Year. Ministry of Finance Planning and Economic Development, Govemment of Uganda, Kampala-Uganda.

Miller, R.E., and Blair,P.D., (2009). Input-Output Analysis: Foundations and Extensions. Cambridge University Press 2 edition .

MFPED., (2011). Budget Speech for the 2013/14 Fiscal Year. Ministry of Finance Planning and Economic DevelopmentGovemment of Uganda Kampala-Uganda.

Moe, T., (2010). Norwegian Climate Policies 1990-2010: Principles, Policy Instruments and Political Economy Aspects; CICERO Policy Note 2010:03; Center for International Climate and Environmental Research (CICERO): Blindern, Norway, 2010.

MWE., (2009). Strategic Sector Investment Plan for the Water and Sanitation Sector in Uganda, Ministry of Water and Environment-Government of Uganda. [On-line]. Available from: http://mwe.go.ug. Accessed on 13thNov 2013

Nichols, A.L., (1984). Targeting Economic Incentives for Environmental Protection, MTT Press: Cambridge Mass. and London.

NWSC., (2011), Annual Report 2010-2011, National Water and Sewerage Corporation, Kampala-Uganda.

Oates, W.E., (1995). Green taxes: Can we protect the environment and improve the tax system at the same time? Southem Econ. J.,61,915-922.

OECD., (2010b).The Price of Saving Water", The OECD Observer, July 2010.

Olmstead, S.M., (2010). The Economics of Water Quality, Review of Environmental Economics and Policy, 4 (1), pp. 44-62.

OPM., (2012). The 2010-2011 Integrated rainfall variability impacts, needs assessment and drought risk management strategy, Department of Disaster Management-Office of the Prime Minister, Govemment of Uganda. 
Patuelli, R., Nijkamp, P., and Pels, E., (2005). Environmental tax reform and the double dividend: A meta-analytical performance assessment. Ecol. Econ., 55, 564-583.

Pearce, D., (1991). The role of carbon taxes in adjusting to global warming. Econ. J, 101, 938-948.

Perry, CJ., Rock, M., and Seckler, D., (1997). Water as an Economic Good: A Solution or a problem?, Research Report for the Intemational Irrigation Managment Institute, Colombo.

Pigou, A. C., (1920). The Economics of Welfare, Macmillan, New York.

Prüss, A., and Havelaar, A., (2001). The Global Burden of Disease study and applications in water, sanitation and hygiene. In: Fewtrell L, Bartram J, editors. Water Quality: Guidelines, Standards and Health. Risk assessment and management for waterrelated infectious disease. IWA Publishing, London. pp. 43-59.

Pulido-Velázquez, M., Andreu, J., Sahuquillo, A., and Pulido-Velázquez, D., (2008). Hydro-economic river basin modelling: the application of a holistic surface-groundwater model to assess opportunity costs of water use in Spain. Ecological Economics Special Issue Integrated Hydro-Economic Modelling.

Qin, C., Yangwen, J., Su, ZB, Hans, T.B., and Wang, H., (2012). The economic impact of water tax charges in China: A static computable general equilibrium analysis, Water Intemational, 37:3, 279-292.

Rausch, S., and Reilly,J., (2012). Carbon Tax Revenue and the Budget Deficit: A Win-Win-Win Solution? Report No.228,MIT Program on the Science and Policy of Global Change. [Online] Available at: http:/globalchange.mit.edu/files/document/MTIJPSPGC_Rpt228.pdf. Accessed on [22 February 2014]

Rose, A., Cao, Y., and Oladosu, G., (2000). Simulating the economic impacts of climate change in the Mid-Atlantic Region.Vol 14:p. 175-183 Department of Energy, Environmental, and Mineral Economics and Centre for Integrated Assessment. [Published 2May 2000].

Rosegrant M.W., and Meijer, S., (2002). Appropriate food policies and investments could reduce child malnutrition by $43 \%$ in 2020. J Nutrition 132: 3437S-40S.

Rosegrant, M. W., Ximing , C,., and Cline, S. A., (2007). "Water. Global Water Outlook to 2025: Averting an Impending Crisis," New England Journal of Public Policy: Vol. 21: Issue. 2, Article 11.

Rosegrant, M.W., Cai, X., and Cline, S.A., (2002). World water and food to 2025: Dealing with scarcity. International Food Policy Research Institute, Washington.

Sahibzada, S.A., (2002). "Pricing Imigation Water in Pakistan: An Evaluation of Available Options," The Pakistan Development Review 41(3): 209-241.

Sanchez P.A., and Swaminathan, M.S.,(2005). Hunger in Africa: the link between unhealthy people and unhealthy soils. Lancet 365: 442-444. doi: 10.1016/S0140-6736(05)17834-9.

Sartzetakis, E., and Tsigaris P.D., (2009). Uncertainty and the Double Dividend Hypothesis, Environment and Development Economics,14,(5), pp 565-585.

Schöb, R., (2009). Climate policy: Choosing the right instrument to reap an additional employment dividend, School of Business and Economics Discussion Paper, No. 2009/10, ISBN 978-3-941240-04-9. [On-line]. Available at: http:/www. econstor. eu/bitstream/10419/28099/1/608758787.PDF.

Seckler, D., Amarasinghe, U., Molden, D., De Silve, R., and Barker, R., (1998).World water demand and supply, 1990 to 2025 : Scenarios and issues. Research Report 19. Intemational Water Management Institute, Colombo, Sri Lanka. 
Shackleton, R., Shelby, M., Cristofaro, A., Brinner, R., Yanchar, J., Goulder, L.H., Jacobsen, M., Wilcoxen, PJ., Pauly, P., and Kaufmann, R., (1993). The Efficiency Value of Carbon Tax Revenues. In Energy Modeling Forum; Terman Engineering Center, Stanford University: Stanford, CA, USA.

SIWI., (2005). Making water a part of economic development: the economic benefits of improved water management and services. Stockholm: Stockholm Intemational Water Institute.

Spratt, S., (2012). Environmental Taxation and Development: A Scoping Study. ICTD Working Paper 2, Institute of Development Studies. [Online] Available at:

http://www.ictd.ac/sites/default/files/ICTD\%20Working\%20Paper2_Spratt,\%20June2012.pdf.

Terkla, D., (1984). “The Efficiency Value of Effluent Tax Revenues", Journal of Environmental Economics and Management $11,107-123$.

Thurlow, J., (2008). "A 2007 agriculture-focused social accounting matrix for Uganda: preliminary with revised national accounts", International Food Policy Research Institute, Washington, D.C.

Tol, R., Berittella, M., Rehdanz, K., and Roson, R., (2008). The Economic Impact of Water Taxes: A Computable General Equilibrium Analysis with an Intemational Data Set. University Ca' Foscari of Venice, Dept. of Economics Research Paper Series No. 05/08. Available at SSRN: http://ssm.com/abstract=1 105000 or http://dx.doi.org/10.2139/ssm.1105000

Tullock, G., (1967). ‘Excess Benefit”, Water Resources Research3, 643-644.

United Nations., (2007). The Millennium Development Goals Report. New York: United Nations. Available: http://www.un.org/millenniumgoals/pdf/mdg2007.pdf.

Van Heerden J.H., Blignaut J.N., Mabugu, M., Gerlagh, R., Hess, S., Tol, R., Horidge, M., Mabugu, R., De Wit, M.P., and Letsoalo, A., (2006). Redistributing environmental tax revenue to reduce poverty in South Africa: the cases of energy and water. S. Afr. J. Econ. Manage. Sci. 9(4) 537-552.

Venkataramani, A., (2009). The long-run and intergenerational effects of early life experiences: Evidence from developing countries, $\mathrm{PhDd}$ dissertation, Yale University.

Wittwer, G., and Kym, A., (2001). Impact of Tax Reform on the Austrian Wine Industry: A CGE analysis, Discussion Paper No. 9908. Centre for International Economic Studies.

Wittwer, G.,(2011), “Confusing policy and catastrophe: buybacks and drought in the Murray-Darling Basin”, Economic Papers 30(3): 289-295.

WWC.,(2006). The Right to Water:From Concept to Implementation, Marseilles: World Water Council

Yang, H., Reichert, P., Abbaspour, K.C., and Zehnder, A., (2003). A water resources threshold and its implications for food security. In: Hoekstra, A.Y.(Ed.), Virtual Water Trade: Proceedings of the International Expert Meeting on Virtual Water Trade, Delft, The Netherlands, 12-13 December 2002, pp.111-116.

Yusuf, A., and Resosudarmo, B.P., (2007). On the Distributional Effect of Carbon Tax in Developing Countries: The Case of Indonesia. Working Paper No. 200705, Centre for Economics and DevelopmentStudies.

Zhou, R., and Segerson, K., (2012). Are Green Taxes a Good Way to Help Solve State Budget Deficits? Sustainability, 4, 13291353; doi: $10.3390 /$ su4061329. 